\title{
PENGARUH JIGSAW TERHADAP PRESTASI BELAJAR SISWA KELAS VII SMP NEGERI O3 POLOKARTO SUKOHARJO
}

\author{
Nendita Ayu Ketut Fatmawati, Dewi Susilowati, Andhika Ayu Wulandari \\ Universitas Veteran Bangun Nusantara, Sukoharjo \\ nenditaketut3010@gmail.com
}

\begin{abstract}
Abstrak
Tujuan penelitian ini adalah untuk mengetahui apakah ada pengaruh penggunaaan model pembelajaran kooperatif tipe jigsaw terhadap prestasi belajar matematika pokok bahasan aritmatika sosial pada siswa kelas VII SMP Negeri 03 Polokarto tahun pelajaran 2018/2019. Jenis penelitian yang digunakan adalah eksperimen semu. Populasi dalam penelitian adalah seluruh siswa kelas VII SMP Negeri 03 Polokarto dan sampel penelitian yaitu kelas VII A sebagai kelas kontrol dan kelas VII D sebagai kelas eksperimen yang dipilih menggunakan cluster random sampling. Data yang dikumpulkan terdiri dari dokumen Penilaian Akhir Semester (PAS) ganjil untuk uji keseimbangan awal dan tes untuk uji prestasi belajar setelah perlakuan. Berdasarkan data diperoleh rata-rata nilai tes prestasi belajar siswa untuk kelas eksperimen sebesar 71,250 dan untuk kelas kontrol sebesar 66,125. Dari perhitungan uji-t diperoleh harga $t_{\text {hitung }}=2,600$ sedangkan harga $t_{\text {tabel }}=1,999$ dengan taraf signifikan $5 \%$. Karena $t_{\text {hitung }}>t_{\text {tabel }}$, maka $\mathrm{H}_{0}$ ditolak. Jadi dapat disimpulkan bahwa ada pengaruh penggunaan model pembelajaran kooperatif tipe jigsaw terhadap prestasi belajar matematika pokok bahasan aritmatika sosial pada siswa kelas VII SMP Negeri 03 Polokarto Kabupaten Sukoharjo Tahun Pelajaran 2018/2019.
\end{abstract}

Kata Kunci: Jigsaw, Prestasi Belajar

\begin{abstract}
The objective of the research is to determine whether there was an influence of using jigsaw type in cooperative learning model toward mathematics learning achievement on social arithmetic at seventh grade students of SMP Negeri 03 Polokarto in the academic year of 2018/2019. The type of the research is quasi-experimental. The population in this research was all the seventh grade students of SMP Negeri 03 Polokarto and the samples were class VII A as the control class and class VII D as the experimental class that was taken by cluster random sampling. The data collection consisted of an odd Semester Final Assessment (PAS) that was used for the initial balance test and test was used to collect the data of learning achievement after treatment. Based on the data obtained the average test scores of the student achievement for the experimental class amounted to 71,250 and for the control class amounted to 66,125. From the t-test calculation obtained $t_{\text {hitung }}=2,600$ while $t_{\text {table }}=1,999$ with a significant level of $5 \%$. Because of $t_{\text {hitung }}>t_{\text {table, }}$, then $H_{o}$ is rejected. So it can be concluded that there is the influence of using jigsaw type in cooperative learning model toward mathematics learning achievement on social arithmetic at seventh grade students of SMP Negeri 03 Polokarto in the academic year of 2018/2019.
\end{abstract}

Keywords: Jigsaw, Learning Achievement

\section{Pendahuluan}

Menurut Ismail (2012:9), pada hakikatnya pendidikan itu adalah usaha meningkatkan kualitas kehidupan baik secara pribadi maupun masyarakat. Pendidikan berwujud aktivitas interaktif yang sadar dan terencana. Dilakukan oleh minimal dua orang, satu pihak berperan sebagai fasilitator dan dinamisator sedang pihak lainnya sebagai subyek yang berupaya 
mengembangkan diri. Proses dicapai melalui penciptaan suasana belajar dan proses pembelajaran. Berkaitan dengan proses pembelajaran, paradigma mengajar di Indonesia mempunyai ciri-ciri antara lain guru lebih mendominasi proses pembelajaran, pemahaman peserta didik cenderung bersifat instrumental, peserta didik hanya diam secara fisik dan kurang konsentrasi memperhatikan apa yang diajarkan oleh guru (Taufiq, 2018:85). Pencapaian tujuan pembelajaran berupa prestasi belajar merupakan hasil dari kegiatan belajar mengajar. Sedangkan prestasi belajar adalah hasil belajar peserta didik yang dapat diukur dari nilai siswa setelah mengerjakan soal yang diberikan oleh guru pada saat evaluasi dilakukan (Siagian, 2012:123). Upaya untuk mencapai prestasi belajar antara lain dengan menerapkan model pembelajaran inovatif dalam penciptaan suasana belajar dan proses pembelajaran (Arikunto, 2012:4).

Menurut Suprijono (2015:65) model pembelajaran ialah pola yang digunakan sebagai pedoman dalam merencanakan pembelajaran di kelas maupun tutorial. Memilih model pembelajaran yang tepat oleh guru akan berpengaruh pada cara belajar siswa. Jika cara mengajar guru disukai oleh siswa, maka siswa akan antusias, rajin dan tekun dalam menerima pembelajaran sehingga diharapkan dapat meningkatkan prestasi belajar siswa. Proses Pembelajaran yang menarik dapat terlaksana dengan model pembelajaran yang sesuai dengan karakteristik siswa (Suprapti, 2018:25)

Menurut Sugianto, Dian Armanto dan Mara Bangun Harahap (2014:96) mata pelajaran matematika merupakan salah satu mata pelajaran yang menjadi perhatian utama, dan dalam kenyataannya, matematika masih merupakan pelajaran yang sulit dipelajari oleh siswa bahkan merupakan pelajaran yang menakutkan bagi sebagian besar siswa. Selain matematika dikenal sebagai pelajaran yang sulit, matematika juga dikenal sebagai pelajaran yang berisi rumus-rumus (Ningsih, Budiyono dan Riyadi, 2013:479-480). Pemahaman tentang ide atau gagasan matematika yang dimiliki seseorang memiliki manfaat dalam menyelesaikan suatu permasalahan dalam kehidupannya, sehingga penting bagi manusia untuk mempelajari matematika (Hidayah, 2018:169).

Berdasarkan data hasil wawancara di SMP Negeri 03 Polokarto Kabupaten Sukoharjo pada pembelajaran matematika, menunjukkan $87,5 \%$ siswa yang belum memenuhi Kriteria Kelulusan Minimal (KKM) dan KKM yang ditetapkan oleh sekolah adalah 70. Secara umum rendahnya prestasi belajar siswa disebabkan karena tidak sesuainya model pembelajaran yang diterapkan guru. Menurut Hidajat (2015:195) disisi lain banyak siswa yang tidak menyenangi mata pelajaran matematika. Siswa tidak menyenangi mata pelajaran matematika secara tidak langsung berpengaruh terhadap rendahnya prestasi belajar. Peningkatan mutu pendidikan dasar 
secara umum dan mutu pelajaran matematika secara khusus diperlukan perubahan pola pikir positif, salah satunya dengan menerapkan permainan edukatif sebagai media pembelajaran (Astutiningtyas, 2015:188). Selama ini masih banyak guru yang menyampaikan materi dengan model pembelajaran konvensional sehingga siswa hanya beraktifitas mendengarkan saja dan konsep-konsep yang disampaikan guru hanya bisa dihafalkan tanpa ada pemahaman yang berarti. Untuk itu diperlukan alternatif penerapan model pembelajaran dimana belajar harus dilakukan oleh siswa dengan cara menempatkan siswa secara berkelompok-kelompok, sehingga dapat melatih siswa dalam berfikir kritis, kreatif, dan menumbuhkan rasa sosial yang tinggi. Guru hanya bertindak memfasilitasi dan memotivasi siswa sehingga guru membutuhkan model pembelajaran yang sesuai untuk membantu siswa memahami konsep-konsep yang disampaikan.

Model pembelajaran yang memungkinkan untuk diterapkan antara lain Jigsaw, Student Teams Achievement Division (STAD), Number Heads Together (NHT), Grup Investigation (GI) dan lain sebagainya. Model pembelajaran yang tepat digunakan pada pokok bahasan aritmatika sosial dengan kondisi siswa di SMP Negeri 03 Polokarto Kabupaten Sukoharjo adalah jigsaw. Model pembelajaran tipe jigsaw tidak hanya menginginkan siswa untuk belajar keterampilan dan isi akademik, tetapi juga melatih siswa dalam mencapai tujuan-tujuan hubungan sosial dan manusia, yang pada akhirnya berpengaruh terhadap prestasi akademik siswa (Sugianto, 2014:119). Jigsaw adalah sebuah model belajar kooperatif yang menitik beratkan pada kerja kelompok siswa dalam bentuk kelompok kecil (Huda dan Arief, 2013:35).

Model pembelajaran kooperatif tipe jigsaw menjadi salah satu model yang dapat berpengaruh dalam menciptakan suasana kegiatan belajar dan mengajar yang menyenangkan dan menarik bagi siswa. Diharapkan dengan suasana menyenangkan siswa kelas VII SMP Negeri 03 Polokarto Kabupaten Sukoharjo tahun pelajaran 2018/2019 dapat memahami materi aritmatika sosial dengan optimal sehingga berdampak positif pada prestasi belajar matematika.

Rumusan masalah yang akan dikaji adalah "Apakah ada pengaruh model pembelajaran kooperatif tipe jigsaw terhadap prestasi belajar matematika pokok bahasan aritmatika sosial pada siswa kelas VII SMP Negeri 03 Polokarto Kabupaten Sukoharjo tahun pelajaran 2018/2019?”. Sedangkan tujuan penelitian ini adalah untuk mengetahui apakah ada pengaruh model pembelajaran kooperatif tipe jigsaw terhadap prestasi belajar matematika pokok bahasan aritmatika sosial pada siswa kelas VII SMP Negeri 03 Polokarto Kabupaten Sukoharjo tahun pelajaran 2018/2019. 


\section{Metode Penelitian}

Penelitian ini dilaksanakan di SMP Negeri 03 Polokarto Kabupaten Sukoharjo tahun pelajaran 2018/2019. Waktu yang diperlukan dalam penelitian ini mulai dari tahap persiapan sampai dengan penyusunan laporan yaitu selama lima bulan dari bulan Januari - Juni 2019 .

Penelitian ini merupakan jenis penelitian eksperimen, karena dalam penelitian sengaja membuat agar ada variabel yang hadir kemudian diteliti dan dicermati bagaimana dampaknya (Arikunto, 2013:19). Berdasarkan metode penelitian yang digunakan, penelitian ini menggunakan desain penelitian eksperimen semu (quasi experimental design). Sebelum diberi perlakuan, terlebih dahulu akan dilihat kemampuan awal dari sampel penelitian yang dikenai perlakuan, baik dari kelas eksperimen maupun kelas kontrol. Tujuannya untuk mengetahui apakah kemampuan awal kedua kelas dalam keadaan seimbang. Data yang digunakan untuk uji keseimbangan adalah nilai dari Penilaian Akhir Semester (PAS) I siswa kelas VII untuk mata pelajaran matematika tahun pelajaran 2018/2019.

Pada penelitian ini yang akan menjadi populasinya yaitu seluruh siswa kelas VII SMP Negeri 03 Polokarto Kabupaten Sukoharjo Tahun Ajaran 2018/2019 yang terdiri dari 5 kelas dengan jumlah siswa adalah 160 dan yang menjadi sampel dalam penelitian ini yaitu kelas VII A dan VII D yang masing-masing berjumlah 32 siswa. Teknik pengambilan sampel yang dilakukan dalam penelitian ini adalah dengan cluster random sampling

Teknik pengumpulan data yang digunakan dalam penelitian ini adalah dokumentasi dan tes. Menurut Arikunto (2013:274), “metode dokumentasi yaitu mencari data mengenai hal-hal atau variabel yang berupa catatan, transkip, buku, surat kabar, majalah, prasasti, notulen rapat, lengger, agenda, dan sebagainya". Pada penelitian ini, metode dokumentasi digunakan untuk mengetahui daftar nama, nomor absen siswa, mendapatkan data tentang Penilaian Tengah Semester (PTS) mata pelajaran matematika pada kelas VII semester I tahun pelajaran 2018/2019 untuk uji normalitas dan uji keseimbangan.

Tes adalah serentetan pertanyaan atau latihan serta alat lain yang digunakan untuk mengukur keterampilan, pengetahuan intelegensi, kemampuan atau bakat yang dimiliki oleh individu atau kelompok (Arikunto, 2013:193). Metode tes dalam penelitian ini digunakan untuk mengumpulkan data mengenai prestasi belajar matematika. Pada instrumen tes harus diuji cobakan terlebih dahulu. Adapun langkah-langkah yang dilakukan pada uji coba /instrumen tes yaitu uji validitas, uji reabilitas, uji derajad kesukaran, dan uji daya beda. Teknik analisis data pada penelitian ini menggunakan uji t. Langkah-langkah pengujiannya ada 2 tahap yaitu sebagai berikut: (1) Analisis data tahap awal yang terdiri dari uji prasyarat analisis (uji normalitas, uji 
homogenitas) dan uji keseimbangan (2) Analisis data tahap akhir yang terdiri dari uji prasyarat analisis (uji normalitas, uji homogenitas) dan uji hipotesis.

\section{Hasil dan Pembahasan}

Berdasarkan pengumpulan data dalam metode dokumentasi diperoleh data-data siswa seperti nama siswa, kelas siswa dan nilai PAS, dari tersebut diperoleh :

Tabel 1.Keadaan awal siswa

\begin{tabular}{ccccc}
\hline Kelas & Jumlah Siswa & Rata-rata & Standar Deviasi & Variansi \\
\hline Eksperimen & 32 & 50,969 & 12,683 & 160,870 \\
Kontrol & 32 & 57,844 & 15,160 & 229,814 \\
\hline
\end{tabular}

Dengan data awal tersebut didapatkan hasil analisis uji normalitas dengan metode Liliefors sebagai berikut:

Tabel 2.Hasil perhitungan uji normalitas

\begin{tabular}{cccc}
\hline Sampel & Lhitung & Ltabel & Keputusan Uji \\
\hline Kelas Eksperimen & 0,079 & 0,157 & Karena $\mathrm{L}_{\text {hitung }}<\mathrm{L}_{\text {tabel }}$ maka $\mathrm{H}_{0}$ tidak ditolak \\
Kelas Kontrol & 0,142 & 0,157 & Karena $\mathrm{L}_{\text {hitung }}<\mathrm{L}_{\text {tabel }}$ maka $\mathrm{H}_{0}$ tidak ditolak \\
\hline
\end{tabular}

Dari tabel di atas dapat disimpulkan kedua kelas baik kelas ekperimen maupun kelas kontrol diperoleh $\mathrm{L}_{\text {hitung }}<\mathrm{L}_{\text {tabel }}$ maka disimpulkan kedua kelas berdistribusi normal.

Selanjutnya data awal tersebut diuji homogenitasnya untuk mengetahui apakah kedua populasi mempunyai variansi yang sama atau homogen. Dari perhitungan diperoleh $\mathrm{F}_{\text {Hitung }}=$ 0,700 dan $F_{(31 ; 31 ; 0,025)}=2,049$. Dengan demikian menunjukkan bahwa $F_{\text {Hitung }}<F_{(31 ; 31 ; 0,025)}$, sehingga $\mathrm{H}_{0}$ tidak ditolak atau dapat ditarik kesimpulan bahwa variansi kedua kelas adalah sama atau homogen. Kemudian dari perhitungan uji keseimbangan menggunakan uji t, diperoleh $\mathrm{t}_{\text {Hitung }}=-1,968$ dan $\mathrm{t}_{\text {Tabel }}=-1,999$, karena $-1,999<-1,968<1,999 ;-\mathrm{t}_{\text {Tabel }}<\mathrm{t}_{\text {Hitung }}<\mathrm{t}_{\text {tabel }}$ maka $\mathrm{H}_{0}$ tidak ditolak. Sehingga dapat disimpulkan bahwa kemampuan awal kedua kelompok adalah sama atau seimbang.

Setelah itu kedua sampel diberi perlakuan yang berbeda, kelas eksperimen menggunakan model pembelajaran jigsaw dan kelas kontrol dengan model konvensional. Selanjutnya kedua sampel diberikan intrumen tes berupa soal pilihan ganda sebanyak 45 soal. Dari nilai hasil tes tersebut dapat dilakukan analisis perhitungan uji normalitas, uji homogenitas, dan uji hipotesis. 
Tabel 4. Data Akhir Siswa

\begin{tabular}{ccccc}
\hline Kelas & Jumlah Siswa & Rata-rata & Standar Deviasi & Variansi \\
\hline Eksperimen & 32 & 71,250 & 7,144 & 51,032 \\
Kontrol & 32 & 66,125 & 8,560 & 73,274 \\
\hline
\end{tabular}

Uji normalitas menggunakan metode liliefors dengan taraf signifikan 5\% sebagai berikut :

Tabel 5.Hasil Perhitungan Uji Normalitas

\begin{tabular}{cccc}
\hline Sampel & L hitung & Ltabel & Keputusan Uji \\
\hline Kelas Eksperimen & 0,126 & 0,157 & Karena $\mathrm{L}_{\text {hitung }}<\mathrm{L}_{\text {tabel }}$ maka $\mathrm{H}_{0}$ tidak ditolak \\
Kelas Kontrol & 0,153 & 0,157 & Karena $\mathrm{L}_{\text {hitung }}<\mathrm{L}_{\text {tabel }}$ maka $\mathrm{H}_{0}$ tidak ditolak \\
\hline
\end{tabular}

Dari tabel di atas dapat disimpulkan kedua kelas baik kelas ekperimen maupun kelas kontrol diperoleh $\mathrm{L}_{\text {hitung }}<\mathrm{L}_{\text {tabel }}$ maka disimpulkan kedua kelas berdistribusi normal.

Selanjutnya dilakukan uji homogenitas untuk mengetahui homogen tidaknya variansi sampel yang diambil dari populasi yang sama. Hasil perhitungan uji homogenitas diperoleh $F_{\text {Hitung }}=0,696$ dan $F_{(31 ; 31 ; 0,025)}=2,049$. Dengan demikian menunjukkan bahwa $F_{\text {Hitung }}<$ $F_{(31 ; 31 ; 0,025)}$, sehingga $\mathrm{H}_{0}$ tidak ditolak atau dapat ditarik kesimpulan bahwa variansi kedua kelas adalah homogen. Setelah dilakukan uji normalitas dan uji homogenitas prestasi belajar matematika yang menunjukan bahwa data hasil tes prestasi tersebut berdistribusi normal dan variansi-variansi berasal dari populasi yang homogen, maka dilanjutkan dengan uji t. Dari perhitungan uji hipotesis menggunakan uji $\mathrm{t}$ setelah dilakukan perlakuan diperoleh $t_{\text {Hitung }}=$ 2,600 dan $t_{\text {Tabel }}=1,999$, karena $t_{\text {Hitung }}>t_{\text {tabel }}$ maka $\mathrm{H}_{0}$ ditolak. Dengan demikian dapat disimpulkan bahwa ada pengaruh model pembelajaran kooperatif tipe Jigsaw terhadap prestasi belajar matematika pokok bahasan aritmatika sosial pada siswa kelas VII SMP Negeri 03 Polokarto Kabupaten Sukoharjo tahun ajaran 2018/2019.

\section{Simpulan dan Saran}

Berdasarkan hasil penelitian dapat ditarik simpulan bahwa ada pengaruh model pembelajaran kooperatif tipe Jigsaw terhadap prestasi belajar matematika pokok bahasan aritmatika sosial pada siswa kelas VII SMP Negeri 03 Polokarto Kabupaten Sukoharjo tahun ajaran 2018/2019. Peneliti sarankan bagi siswa untuk lebih berperan aktif dalam mengikuti tahapan pembelajaran yang diterapkan guru, yaitu model pembelajaran kooperatif tipe jigsaw sehingga prestasi belajar matematika siswa akan lebih baik daripada model pembelajaran konvensional. 


\section{Referensi}

Arikunto, Suharsimi. 2012. Dasar-Dasar Evaluasi Pendidikan. Cet.Ke-2. Jakarta:Bumi Aksara. 2013. Prosedur Penelitian. Cet.Ke-15. Jakarta:Rineka Cipta.

Astutiningtyas, Laras Erika, Andhika Ayu Wulandari, Januar Budi Asmari. 2015. Perancangann Oktagram Sebagai Media Pembelajaran Geometri Sekolah Dasar. Jurnal Math Educator Nusantara. Vol. 01, No. 02, Nopember 2015. Hal 187-194.

Hidajat, Djatmiko, Dewi Susilowati dan Mei Wijayanti. 2013. Pengaruh Model Pembelajaran Cooperatif Integrated Reading And Composition Terhadap Prestasi Belajar Matematika Siswa SMP Negeri 3 Grogol Sukoharjo. Jurnal Math Educator Nusantara. Vol. 01, No. 02, Tahun 2013. Hal 195-203.

Hidayah, Isnaini Nikken, Vina Dwi Riski, dkk. 2018. Pengaruh Penggabungan Metode Outdoor dengan Indoor Learning Menggunakan Sistem Sepur Selam. Jurnal Math Educator Nusantara. Vol. 4, No. 2. Nopember 2018, Hal. 168-176

Huda, Miftachul dan Alimufi Arief. 2013. Pengaruh Multiple Intelligences Menggunakan Model Pembelajaran Kooperatif Tipe Jigsaw Tehadap Hasil Belajar Siswa Pada Pokok Bahasan Listrik Dinamis Kelas X di SMAN 1 Porong. Jurnal Inovasi Pendidikan Fisika. Vol. 02, No. 03, Tahun 2013. Hal. 35

Ismail. 2012. Ilmu Pendidikan. Cet.Ke-1. Sukoharjo:Univet Bantara Press.

Ningsih, Sri Hartati, Budiyono dan Riyadi. 2013. "Eksperimentasi Model Pembelajaran Kooperatif Tipe Group Investigation (GI) dan Think Pair Share (TPS) pada Materi Trigonometri Ditinjau dari Kecerdasan Logika Matematika Siswa Kelas X SMA di Kabupaten

Sukoharjo". http://jurnal.fkip.uns.ac.id/index.php/s2math/article/view/3521/2455 (diakses pada 25 November 2018)

Siagian, Roida, Eva, Flora. 2012. Pengaruh Minat dan Kebiasaan Belajar Siswa Terhadap Prestasi Belajar Matematika. Jurnal Formatif 2(2):122-131

Sugianto, Dian Armanto, dan Mara Bangun Harahap. 2014. Perbedaan Penerapan Model Pembelajaran Tipe Jigsaw dan STAD Ditinjau dari Kemampuan Penalaran dan Komunikasi Matematis Siswa. Jurnal Dikdatik Matematika. Vol. 1, No. 1, April 2014. Hal. 96-128

Suprapti, Endang. 2018. Penerapan Teori Belajar Kontruktivisme Untuk Meningkatkan Hasil Belajar Mahasiswa Pada Mata Kuliah Matematika Dasar. Majamath. Vol.1, No. 1, Maret 2018. Hal. 25-32

Suprijono, Agus. 2015. Cooperatif Learning Teori dan Aplikasi Paikem. Yogyakarta:Pustaka Pelajar

Taufiq. 2018. Keefektifan Pembelajaran Matematika Realistik Pada Siswa Kelas VII SMP Negeri 18 Makasar. Majamath. Vol. 1, No. 2, September 2018. Hal. 84-89 